\section{Seismological Association Meeting in Toronto}

THE report of the meetings of the Section for Seismology and the Physics of the Earth's Interior, prepared by the associate secretary, Dr. Markus Båth, of Sweden, has recently been published (pp. 448. Strasbourg: Bureau Central International de Séismologie, 1958). Most of the subdivisions into which this subject may be divided were discussed in the twenty-two sessions. Detailed reports of these meetings, the presidential address by Prof. K. E. Bullen, of the University of Sydney, the report of the meeting of the European Seismological Commission, the Committee of the International Seismological Summary and the Committee for the International Geophysical Year are included. In addition, there are seismological reports from thirty-four countries, and the resolutions adopted at the assembly. The whole covers some 455 quarto pages. At the conference, ten sessions were devoted to seismology alone, six to joint meetings with the Association of Volcanology and two to joint meetings with the Association of Geodesy. It was at an extra session at Toronto that Prof. K. E. Bullen announced that the U.S. Atomic Energy Commission had released information concerning the time and place of a future underground nuclear detonation in Nevada, so that seismologists could prepare to participate in the recording. The International Geophysical Year Committee discussed particularly the recording of earthquakes with epicentres in the arctic and antarctic regions; and it is noteworthy that M. E. Guyot is proceeding with the preparation of a seismological dictionary which it is hoped will be published without delay.

\section{Soil Survey of Great Britain}

THE soil survey of Great Britain, with headquarters at Rothamsted, will occupy many years, and reports are to be published as each county is completed. The magnitude of the task can be realized from the memoir on Anglesey (Agricultural Research Council. Memoirs of the Soil Survey of Great BritainEngland and Wales. The County of Anglesey : Soils and Agriculture. By E. Roberts. Pp. viii + $116+11$ plates. London : H.M. Stationery Office, 1958, 10s. net), which includes also a small proportion of Caernarvonshire; nearly fifty soil series, which are the mapping units, are identified and described. Anglesey is relatively flat, but there are considerable variations in the land surface due to the rugged outcrops of the Mona complex, the sharp escarpment of the Carboniferous limestones, the igneous rocks, wind-blown sands and glacial features. The varying thickness of the boulder clay has contributed to the irregular undulations of most of the fields.

Classification and mapping of the soils are based on the soil profile, since it reflects the action and balance of the many processes that have led to its formation; drainage has a profound effect, and is taken into account in the classification. Although familiar to soil scientists and to many advisory officers, the subject is new to workers in related subjects, and to farmers. The Soil Survey of Great Britain will be the foundation for a planned approach to fertilizer and cropping problems for many years, and such reports will have to be studied, and the maps referred to frequently. The one inch to the mile soil map that is provided may prove too small for reference to some individual farms on or near the margins of the soil areas, but a 6-in. map is available for reference at Rothamsted.

\section{Grassland Productivity}

"'The Measurement of Grassland Productivity" was the subject of the sixth Easter School in Agricultural Science which was held at the University of Nottingham School of Agriculture, Sutton Bonington, during April 13-16, and was organized by Prof. J. D. Ivins. Twenty papers were read, primarily concerned with techniques of grassland evaluation. Assessment of productivity from the botanical point of view, in terms of animal production, the consumption of herbage by grazing livestock and grassland productivity on a farm scale were considered. New varieties of herbage plants have been produced and their requirements have been explored to a great extent. New techniques have been developed which have resulted in vast increases in the production from grassland, but a constant problem and hindrance to development has been-and still is-the lack of methods which may be used with validity to measure and compare grassland productivity. Some 140 members from Britain and overseas exchanged experiences and ideas and discussed the limitations and applications of techniques of measuring the productivity of grassland. The proceedings will be published.

\section{Safety in Mines Research}

THE thirty-sixth annual report on Safety in Mines Research (pp. $81+4$ plates. London: H.M. Stationery Office, 1958. 5s. net) is a general review of progress in the year 1957 of the Safety in Mines Research Establishment of the Ministry of Power. The report describes research undertaken in the general fields of explosives and blasting devices, explosion hazards, breathing apparatus, fire hazards, engineering and metallurgy, dust control and pneumoconiosis hazards, and in certain other fields, together with a record of testing services carried out by the Establishment. A significant feature of some aspects of the work is the active co-operation and interchange of results with kindred establishments in France, Germany and Poland. More than ninety topies are discussed; it is difficult to select individual topics for special mention, but perhaps attention may be directed to the work reported on the fluid mechanics of coal dust explosions, a subject of interest to all concerned with fires and explosions due to organic dusts. There are, in fact, many topics reported which are of interest and importance to several industries in addition to the mining industry, including breathing apparatus, engineering and metallurgical problems of importance in conveying, winding and supports, and the study of dusts and of pneumoconiosis.

\section{Morbidity Statistics from General Practitioners}

IN the series of Studies on Medical and Population Subjects, the first volume of morbidity statistics collected from general practitioners has recently appeared (General Register Office. Studies on Medical and Population Subjects No. 14 : Morbidity Statistics from General Practice, Vol. 1 (General). By Dr. W. P. D. Logan and A. A. Cushion. Pp. iv + 174. London: H.M. Stationery Office, 1958. 15s. $6 d$. net). A number of practitioners agreed to keep records of all consultations with patients on their list, and the General Register Office went to considerable trouble to obtain the correct population at risk to which these consultations could be related. While the practices were not chosen as a representative sample of the total population, this is the 